\title{
Islamic Journalism reporting of the 2019 Indonesian presidential election
}

\author{
Dio Damika Suhenda, Andari Karina Anom \\ \{ddamikasuhenda@gmail.com\} \\ Communication Department, Faculty of Computing and Media, Bina Nusantara University, \\ Jakarta, Indonesia 11480
}

\begin{abstract}
This research analyzed 50 keywords using the aid of NVIVO, sampled from two Indonesian media sites practicing Islamic journalism, to study the relationship between the focus of reporting on the 2019 Indonesian presidential election and its politically oriented journalistic roles. One of the media, voa-islam.com, has been involved in polarizing voters by their faith using an 'us and them' frame. Through content analysis, this research has quantified the political function of the media in question to be rooted in the promotion of one candidate more closely related with hardline Islamic groups; over the other. On the other hand, the more mainstream media, Republika, has proven itself more impartial and objective, although still denominating issues to an Islamic perspective for its Muslim majority audience. Consequently, this research suggests that there needs to be greater policing of journalistic frames applied in the media.
\end{abstract}

Keywords: Communication; Journalism; Media Studies; Politics; Religious Studies

\section{Introduction}

The involvement of religion in Indonesian democracy has only grown insignificance. As such, identity politics based on religion has resulted in the media becoming the new political frontier [1]. With Islam being the most politically charged religion in Indonesia, Islamic journalism can be incredibly dangerous when used to gain political gain. As such, this research ventures to draw correlations between Islamic journalism's focus of reporting on the 2019 presidential election, a key event in the country's development, and this brand of journalism's intended political function. Notably, Islamic journalism now exists in a sphere of media that has been revolutionized by the internet, as it has allowed the flow of information to no longer be passively one-way. Instead, information now actively ebbs and flows from many-to-many in a two-way interaction.

As such, the availability of the Internet as means to spread information has infinitely multiplied the available space for new journalism practices to emerge [2]. Democracy now enjoys and suffers from the concept of citizen journalism, as anyone with an internet connection can become a journalist [3]. This decentralization of journalism has given rise to identity-based journalism and questionable post-truth reporting [4]. Although not inherently problematic, identity-journalism can hinder democracy, as subjectivity is justified under the vigil of a more significant set of beliefs. When the media and religion become increasingly intertwined, ensuring objective journalism becomes difficult; this can harm democracy. 
Contrary to traditional secular arguments, the interlinkage between religion and democracy is inevitable and critical for social stability, where democracy is defined as a societal system operating in a different plane from religion [5]. As put forth by Inglehart (2000), democracy hinges on the grassroots value framework of its citizens [6]. As part of a society's cultural constituent, different faiths will reflect and influence the nature of democracy differently, as apparent in Indonesia.

In reflection of its multifaith populace, the electoral system in Indonesia involves numerous parties openly involving religion, particularly Islam, in their campaigns [7]. Although the electoral system has benefited from nationwide suffrage and large turn-up, democracy still has its problem. The nation now faces the formation of religion-based militant organizations in swaying the political pendulum [8]. The media is not innocent in this matter. The usage of conflict-oriented frames is evident in attacks thrown against incumbent President Joko Widodo, as critics are commonly found in online discourses [9]. This is further evidenced by the electoral campaigning conduct of choice on social media; identity politics through aggressive personal remarks [10].

With that in mind, this research limits itself to focus on Islamic journalism reporting on the 2019 presidential election, as it was punctuated by narratives rooted in Islamic perspectives, polarizing Indonesian voters by their faith [11]. With that in mind, this research defines Islamic journalism simply as a brand of journalism that is guided not by West-oriented journalistic values. Instead, Islamic journalism is a school of thought in journalism that practices journalistic principles and produces journalistic content based on the Qur'an and the Sunnah [12].

After conducting the data collection and analysis process, this research has surmised that Islam, as the overwhelmingly majority religion, will continue to be an essential part of identity politics and a decisive influence in elections.

\section{Literature Review}

\subsection{Contextualizing Indonesia}

Instead of producing objective journalism coverage, contemporary Indonesian media have instead objectified political development as another media commodity [13]. Indonesian media oligarchs influence reporting framing as they exercise the media's inherent political power [14]. On a more individual level, the socio-cultural backgrounds and framework of value, such as religion, despite the journalist's best efforts, still have the potential to skew reporting [15]. Additionally, conflicting legal regulations have hampered any real progress to police the Indonesian media [16], allowing for polarization of political reporting in the country. In the context of the presidential elections, intensification of conflict by the media can become petty [17]. Backdropped by building tension within the majority Muslim and the state, the media's relationship with religion shows desecularization and resacralization [18]. These forms of religious mediatization have put faith back into the public's attention at the cost of its reliance on the media for relevance. In evidence, the social phenomenon of religious stardom sees religious leaders cultivate public awareness to take full advantage of their popularity in the media [19]. Consequently, the current political landscape is no longer dominated by the state, as the state's powers have been fractionated and are now governed by the different forces of political power in the country [20]. 


\subsection{The 2019 Presidential Election and Islamic Journalism}

The idea that the public is politically well informed is paramount to any democratic landscape. However, most country citizens do not have a clear understanding of the political conditions [21]. At the same time, the media fulfills the individual's need for political orientation as politics occurs beyond an individual's proximity [22], where said individuals are likely only to consume news aligned with their views and strengthen their beliefs socio-political reality [23]. Therefore, the little political knowledge that the citizens consume, based on the media's reporting, contributes over proportionally to their perception of socio-political reality.

On top of their perceived socio-political reality, most Indonesian Muslim populations believe that they should only be led by individuals who share their faith [24]. A previous study conducted by Fossati [25] surmised that most of the research's Muslim respondents agree that Islam should be seen as the first among equals. As such, faith-based coverage through Islamic journalism, geared to appeal to the nation's Muslim population's desires and perceived sociopolitical reality, becomes a powerful electoral asset. The 2019 presidential election indicated numerous religious frictions between the contesting parties, candidates Joko 'Jokowi' Widodo and Prabowo Subianto. Notably, the rise of right-wing Muslim conservatives as political power was in line with Prabowo's first electoral run in 2014 [26]. Upon his election win in 2014, Jokowi's policies starved power away from Muslim hardliners in favor of more liberal alternatives. In response, during the 2019 election, hardline Islamic groups rallied behind Prabowo against their shared political enemy. In reflection of this, Jokowi's approval rating declines along the secular-Islamic spectrum [25].

Despite its illustrious history [27] and universal transcendental values [28], modern Islamic journalism becomes an increasingly crucial tool in Indonesian identity politics [29]. In understanding further the intended political purpose of Islamic journalism, Galtung's (1981) violence-oriented frame [30] becomes relevant. It argues that reporting will focus on adopting a 'zero-sum game' perspective, boiling electoral contests down into two black and white parties, where one party's loss can be equated to the other party's gain. In practice, contesting parties and the media will generally act on any situation as a zero-sum situation [31]. Furthermore, the inherent us against them mindset is further punctuated by repeated slander of the opposition's action reactively, denominated by a populism belief of the perceived morally right majority [32]. As such, the reporting done by Islamic journalism becomes a necessary point of analysis.

RQ1: What are the focus points of Islamic journalism reporting on the 2019 Indonesian presidential election?

\subsection{Theoretical Framework}

This research employed Hanitzsch and Vos' 'Journalistic Role Model' [33] as the theoretical framework. The journalistic role model helps to provide a more relevant framework to distinguish between journalistic roles with functions or intention and consider the institutional context in which it exists. The model has been explicitly designed to counter the overrepresentation of journalistic theories focusing on Western journalism. The journalism role model is designed to be more globally representative in capturing the relationship between journalism, democracy, and societal-political life.

In achieving this, Hanitzsch and Vos outlined six journalistic functions: informationalinstructive, advocative-radical, analytical-deliberative, developmental-educative, criticalmonitorial, and collaborative-facilitative. Furthermore, Hanitzsch and Vos outlined three specific journalistic roles for each position, discussed later in table 1, as part of the methodology codebook. 
The informational-instructive function and its specific roles center on the journalistic part of informing the public for political decisions. The advocative-radical focuses on how journalists position themselves as political actors relevant to the political conflict and how they would facilitate subjective ideologies that enact on them. The analytical-deliberative also places journalists to be active political actors, but instead, concerns itself on how they promote and intervene in political discussions among the masses. The developmental educative emphasizes the involvement of journalists in the promotion of a particular brand of social change through calls to action. The critical monitorial focuses on the fundamental value of the fourth estate, critically keeping political powers in check for the public's good. Lastly, the collaborativefacilitative covers the development journalism aspect, seeing journalists as partners to the state to bring about perceived social progress and protecting the government.

RQ2: What are the most common political functions and roles present during Islamic journalism during reporting on the 2019 Indonesian presidential election?

RQ3: How does Islamic journalism's focus on reporting on the 2019 Indonesian presidential election relate to its politically oriented journalistic roles compared to the mainstream media?.

\section{Research Methods}

The research utilized content analysis of articles published by Islamic journalism news site voa-islam.com. Established in 2009, voa-islam.com has garnered public attention through provocative headlines [34] and was formed to be a reaction against the marginalization of Muslims [35]. Articles from voa-islam.com were then compared to the mainstream Islamic media, Republika. Notably, Republika is the first media to be acknowledged as an Islamic newspaper and is still considered one to the day [27].

Regarding articles from voa-islam.com, the researchers used a purposive sampling method to produce the most relevant sample [36]. Specifically, the criteria considered articles reported on the 2019 presidential election, published during the campaign period, from September 23, 2018, up to April 13, 2019. They included the keywords of the names of either presidential and vice-presidential candidates, their election numbers, or respective political party, in the headline. Resultantly, 356 articles were extracted and became the sample. Regarding articles from Republika, due to the media's larger scale of operation, the research utilized both purposive and constructed week sampling. While keeping the same criteria to provide a fair comparison, constructed week sampling is more effective than simple random sampling [37]. Two completed weeks of articles were sampled to achieve representativeness for the articles belonging to the political category [38]. With that in mind, a sample of 402 articles published from May 31 to April 13, 2019, fitting the criteria, were selected.

For this research, the conceptual content analysis had been deemed most suitable due to its latent nature in quantifying the focus of textual data and drawing conclusions through the frequency and occurrence of most essential keywords [39; 40]. The articles sampled were processed using the NVivo software, as part of the Computer-Aided Text Analysis (CATA) process, due to its ability to process critical quantitative data with high reliability. Like research by Hasan and Dauda [11] and Gandasari and Dwidienawati [41] on the Malay and Indonesian media, respectively, NVivo is suitable to process substantial amounts of textual data and an intuitive approach in content analysis coding. The focus of Islamic journalism's reporting was quantified through the 50 most frequent keywords, aside from conjunctions and prepositions. The 50 keywords from each set of samples, totaling 100 units of analysis, were manually coded 
using a priori codebook design based on the theoretical framework [42; 43]. The coding process considers several factors in designating the appropriate function and role, as displayed in table 1.

Table 1. Codebook conceptual framework

\begin{tabular}{|c|c|}
\hline Function; role & Identifiers (as framed with the units of analysis) \\
\hline Informational-instructive; disseminator & General information, lack of framing, objectivity \\
\hline Informational-instructive; curator & Graphics or other media to curate information \\
\hline Informational- instructive; storyteller & Curation of information, strong framing \\
\hline Advocative-radical; adversary & Hostile or petty tone against government \\
\hline Advocative-radical; advocate & Advocating for an underprivileged social group \\
\hline Advocative-radical; missionary & Promotion of a specific group or ideology \\
\hline Analytical-deliberative; analyst & Contextual frames to criticize an issue \\
\hline Analytical-deliberative; access provider & Medium for an audience to participate in the discussion \\
\hline Analytical-deliberative; mobilizer & Call for the audience to engage in political issues \\
\hline Developmental-educative; change agent & Hopeful tone, framing subject as change bringer \\
\hline Developmental-educative; educator & Informative with data to educate the audience \\
\hline Developmental-educative; mediator & Inclusive frame or pronouns for commonality \\
\hline Critical-monitorial; monitor & A passive critical manner in discussing an issue \\
\hline Critical-monitorial; detective & Involving investigative work \\
\hline Critical-monitorial; watchdog & Active critical fashion to assertively criticize \\
\hline Collaborative-facilitative; facilitator & A government or state friendly frame of reporting, \\
\hline Collaborative-facilitative; collaborator & Visible framing geared to defend the government \\
\hline Collaborative-facilitative; mouthpiece & Justification of government actions \\
\hline
\end{tabular}

Aside from displaying each keyword's word count (n), the research measures the comparative percentage $(\Sigma \mathrm{x})$, a figure indicating the prominence of a keyword denominated by the sum of the top 50 most frequent word count. The coding process has been done by two undergraduate coders that are familiar with journalistic theories. After a one-week training process, a total of 100 keywords, as the unit of analysis, were coded. Based on Krippendorf's alpha [44; 45], a reliability coefficient figure of 96 percent was achieved. 


\section{Results and Discussion}

To answer RQ1, there are patterns of similarities in terms of the focus of Islamic journalism's reporting of the 2019 presidential election, as quantified through notable frequent keywords, across both voa-islam.com and Republika, as illustrated in tables 2 and 3.

Table 2. Voa-islam.com's relevant frequent keywords ordered based on word count

\begin{tabular}{|c|c|c|c|c|c|}
\hline Word & Translation & $\begin{array}{l}\text { Count } \\
\text { (n) }\end{array}$ & $\begin{array}{l}\text { Weighted } \\
\text { percentage }\end{array}$ & $\begin{array}{l}\text { Comparative } \\
\text { percentage }(\mathrm{x})\end{array}$ & Function, Role \\
\hline Grabow & Grabow & 1161 & $1.67 \%$ & $11.92 \%$ & Advocative- radical; missionary \\
\hline Djokovic & Djokovic & 630 & $0.91 \%$ & $6.47 \%$ & Advocative- radical; adversary \\
\hline Indonesia & Indonesia & 470 & $0.68 \%$ & $4.83 \%$ & Developmental- educative; change agent \\
\hline sandi & sandi & 429 & $0.62 \%$ & $4.41 \%$ & Informational- instructive; storyteller \\
\hline president & president & 364 & $0.52 \%$ & $3.74 \%$ & Advocative-radical; adversary \\
\hline rakyat & populace & 291 & $0.42 \%$ & $2.99 \%$ & Developmental- educative; change agent \\
\hline masyarakat & public & 189 & $0.27 \%$ & $1.94 \%$ & Developmental- educative; change agent \\
\hline Politik & politics & 189 & $0.27 \%$ & $1.94 \%$ & Critical- monitorial; monitor \\
\hline bangsa & nation & 181 & $0.26 \%$ & $1.86 \%$ & Developmental- educative; change agent \\
\hline semua & all & 169 & $0.24 \%$ & $1.74 \%$ & Informational- instructive; storyteller \\
\hline Jakarta & Jakarta & 165 & $0.24 \%$ & $1.69 \%$ & Informational-instructive; storyteller \\
\hline partai & party & 165 & $0.24 \%$ & $1.69 \%$ & Advocative- radical; missionary \\
\hline Islam & Islam & 164 & $0.24 \%$ & $1.68 \%$ & Advocative- radical; missionary \\
\hline ekonomi & economy & 155 & $0.22 \%$ & $1.59 \%$ & Critical- monitorial: monitor \\
\hline sandiaga & sandiaga & 124 & $0.18 \%$ & $1.27 \%$ & Informational- instructive; storyteller \\
\hline pemerintah & government & 116 & $0.17 \%$ & $1.19 \%$ & Advocative-radical; adversary \\
\hline subianto & subianto & 115 & $0.17 \%$ & $1.18 \%$ & Informational- instructive; storyteller \\
\hline politics & politician & 102 & $0.15 \%$ & $1.05 \%$ & Critical- monitorial; monitor \\
\hline Jesus & case & 96 & $0.14 \%$ & $0.99 \%$ & Critical- monitorial; monitor \\
\hline ulama & cleric & 95 & $0.14 \%$ & $0.98 \%$ & Advocative- radical; missionary \\
\hline
\end{tabular}

Table 3. Republika's relevant frequent keywords ordered based on word count

\begin{tabular}{|c|c|c|c|c|c|}
\hline Word & Translation & $\begin{array}{l}\text { Count } \\
\text { (n) }\end{array}$ & $\begin{array}{l}\text { Weighted } \\
\text { percentage }\end{array}$ & $\begin{array}{l}\text { Comparative } \\
\text { percentage }(x)\end{array}$ & Function; role \\
\hline Grabow & Grabow & 1386 & $1.51 \%$ & $8.12 \%$ & Informational- instructive; storyteller \\
\hline Djokovic & Djokovic & 1356 & $1.48 \%$ & $7.94 \%$ & Informational- instructive; storyteller \\
\hline president & president & 691 & $0.75 \%$ & $4.05 \%$ & Informational- instructive: disseminator \\
\hline calon & candidate & 509 & $0.56 \%$ & $2.98 \%$ & Informational- instructive: disseminator \\
\hline ma'ruf & ma'ruf & 457 & $0.50 \%$ & $2.68 \%$ & Informational- instructive; storyteller \\
\hline sanding & sanding & 455 & $0.50 \%$ & $2.66 \%$ & Informational- instructive; storyteller \\
\hline 2019 & 2019 & 432 & $0.47 \%$ & $2.53 \%$ & Informational- instructive: disseminator \\
\hline sandi & sandi & 404 & $0.44 \%$ & $2.37 \%$ & Advocative- radical; advocate \\
\hline Jakarta & Jakarta & 347 & $0.38 \%$ & $2.03 \%$ & Informational- instructive: disseminator \\
\hline main & main & 300 & $0.33 \%$ & $1.76 \%$ & Informational- instructive; storyteller \\
\hline Kiai & Kiai & 293 & $0.32 \%$ & $1.72 \%$ & Informational- instructive; storyteller \\
\hline capers & $\begin{array}{l}\text { presidential } \\
\text { candidate }\end{array}$ & 287 & $0.31 \%$ & $1.68 \%$ & Informational- instructive; Disseminator \\
\hline wakil & vice & 269 & $0.29 \%$ & $1.58 \%$ & Informational- instructive; Disseminator \\
\hline subianto & subianto & 231 & $0.25 \%$ & $1.35 \%$ & Informational- instructive: Storyteller \\
\hline
\end{tabular}




\begin{tabular}{|c|c|c|c|c|c|}
\hline widodo & widodo & 226 & $0.25 \%$ & $1.32 \%$ & $\begin{array}{l}\text { Informational - instructive: } \\
\text { Storyteller }\end{array}$ \\
\hline Joko & Joko & 224 & $0.24 \%$ & $1.31 \%$ & $\begin{array}{l}\text { Informational - instructive: } \\
\text { Storyteller }\end{array}$ \\
\hline Negara & state & 193 & $0.21 \%$ & $1.13 \%$ & $\begin{array}{l}\text { Informational - instructive: } \\
\text { Storyteller }\end{array}$ \\
\hline aware & $\begin{array}{l}\text { vice- } \\
\text { presidential } \\
\text { candidate }\end{array}$ & 191 & $0.21 \%$ & $1.12 \%$ & Informational- instructive; Disseminator \\
\hline ulama & cleric & 183 & $0.20 \%$ & $1.07 \%$ & Advocative- radical; advocate \\
\hline Nasional & national & 182 & $0.20 \%$ & $1.07 \%$ & Informational- instructive; Disseminator \\
\hline
\end{tabular}

First, it is essential to note that mentions of both presidential and vice-presidential candidates dominate the overall focus of the reporting. However, there is a significant discrepancy in the proportion of coverage by voa-islam.com on presidential candidate Prabowo Subianto (Prabowo, n:1161; Subianto, n:115) and his vice Sandiaga Uno (Sandi, n:429; Sandiaga, n:124), compared to the other presidential and vice-presidential candidates, Joko Widodo (Jokowi, n:630) and Maruf Amin. Notably, no mention of Maruf Amin even managed to crack the top 50 most frequent keywords from voa-islam.com. On the other hand, Republika achieved almost equal coverage between the two presidential candidates (Prabowo, n:1386; Jokowi, n:1356) and vice-presidential candidates (Sandiaga, n:455; Maruf, n:457). As such, it is observed that voa-islam.com showed significantly greater inclination and active promotion of Prabowo and Sandiaga through sustained coverage, the pair who were closely tied with the hardline Muslim groups during their campaign period [26; 25]. This was indicative of the media's role in appealing to faith-based identity politics, likewise, stated by Hamidah [29].

On top of this discrepancy, attributes of Islam can also be found across both media, with keywords such as Islam (n:164) frequently appearing in voa-islam.com articles, while the keyword 'cleric' also having been noted in both voa-islam.com articles (ulama, n:95), and Republika (ulama, n:183). Notably, mentions of clerics in both reports were found to be associated with well-known Muslim scholars in the country, indicating that both Islamic journalism media depicted tendencies of resacralization and desecularization, as well as religious stardom $[18 ; 19]$.

In a deeper understanding of the focus of reporting of voa-islam.com compared to the more mainstream Republika, it is now pertinent to address RQ2 in analyzing the most common political function and the role the focus is depicted in. Most importantly, these in voa-islam.com articles, as measured through the comparative percentage $(\Sigma x)$, are the adversary role in the advocative-radical function ( $\Sigma \mathrm{x}: 16.71 \%)$, as illustrated in table 4 .

Table 4. voa-islam.com's most familiar political function and role ordered based on the $\Sigma x$.

\begin{tabular}{|c|c|c|}
\hline Function; role & Words & $\begin{array}{l}\text { Sum of comparative } \\
\text { percentage }(\Sigma x)\end{array}$ \\
\hline Advocative- radical; adversary & $\begin{array}{l}\text { Djokovic, president, people, law, presidential election, } \\
\text { government }\end{array}$ & $16.71 \%$ \\
\hline Advocative- radical; missionary & prabowo, party, islam, cleric & $16.27 \%$ \\
\hline Informational- instructive; storyteller & $\begin{array}{l}\text { sandi, all, jakarta, fahri, chief, sandiaga, subianto, } \\
\text { candidate } \\
\text { year, one, daniel, account, percent, vice, vice }\end{array}$ & $14.30 \%$ \\
\hline Informational- instructive; disseminator & presidential candidate, number, national, do, 2018 & $13.02 \%$ \\
\hline Developmental- educative; change agent & Indonesia, populace, public, nation, good & $12.91 \%$ \\
\hline
\end{tabular}


As outlined by this research's theoretical framework, Hanitzsch, and Vos' [33] journalistic role model, the adversary role points to a journalist's tendency to display a hostile tone in placing themselves against the political powers of the government. Voa-islam.com's focus of reporting on topics such as Jokowi (x:6.47\%), his presidency (president, $\mathrm{x}: 3.74 \%)$, and government (pemerintah, $\mathrm{x}: 1.19 \%)$, amongst others, indicated the media's oppositional stance. This was further accentuated by the monitor role in the critical-monitorial function ( $\Sigma x: 9.35 \%)$. Unlike the adversary, the monitor is less hostile, although still focused on identifying political misconduct. Voa-islam.com were found to have reported topics such as politics and politicians (Politik, x:1.94\%; politics, x:1.05\%), the economy (Ekonomi, x:1.59\%), as well as drawing attention to corruption cases during Jokowi's presidency (kasus, x: 0.99\%), in this political role. To juxtapose these findings, the second most prominent political role is the missionary role in the advocating-radical function $(\Sigma \mathrm{x}: 16.27 \%)$. The missionary focuses on the active and subjective promotion of a particular ideology. Topics such as Prabowo (x:11.92\%), affiliated political parties (partai, x:1.69\%), Islam (x:1.68\%), and clerics (ulama, x:0.98\%), amongst others, were all reported in an overly optimistic tone, framed to be heroes of Islam.

This type of framing is further evidenced by the prominence of the storyteller role in the informational-instructive function $(\Sigma x: 14.30 \%)$. This political role provides background information on a topic to achieve the desired contextual frame. Voa-islam.com articles depicted Prabowo and Sandiaga (Subianto, x:1.18\%; Sandi, x:4.41\%; Sandiaga, x:1.27\%), the ranks of political leaders supporting them (Ketua, x:1.45\%); to add credence and legitimacy to this media's preferred candidate. Additionally, storyteller reporting on the capital city of Jakarta (x:1.69\%) and the usage of the pronoun 'all' (sетиa, $\mathrm{x}: 1.74 \%)$ adds another frame of the pair being 'a man of the people.' Lastly, voa-islam.com has been found to employ the change agent role in the developmental-educative function $(\Sigma \mathrm{x}: 12.91 \%)$ when depicting their preferred presidential pairing. As a mediator between the adversary and the missionary, this role chooses to focus instead on developmental journalism while still carrying implicit undertones that the current condition is far from satisfactory. Topics such as the more extraordinary fate of the country (Indonesia, x:4.83\%; Bangsa, x:1.86\%) and the populace (rakyat, x:2.99\%; Masyarakat, $\mathrm{x}: 1.94 \%)$ under Jokowi's presidency were found to be depicted in this manner.

As regards RQ3, this research surmises that the relation between the two variables boils down to the stark contrast between the propaganda depiction of Prabowo, compared to the spiteful slander of Jokowi, as similarly pointed out by Irawanto [10] as well as Herdiansah and Sumadinata [9]. This indicated the zero-sum game at play, as previously argued by Davidai and Ongis [31]. Specifically, voa-islam.com's zero-sum game points to Prabowo being the 'correct' choice for Muslim voters, which polarizes voters by their faith [24]. As such, readers of voaislam.com, most Muslim, would further amplify their desired socio-political reality and orientation, a social phenomenon previously pointed out by Wang [23] and McCombs [22]. In comparing voa-islam.com's focus on its politically oriented journalistic roles against the more mainstream Republika, the matter becomes clear when denominated by the disseminator's role in the informational-instructive function. This role refers to the most fundamental and ideal journalistic purpose of informing objectively. Despite this, voa-islam.com only managed to record a $\Sigma x$ figure of $13.02 \%$. In contrast, Republika achieved a $\Sigma x$ figure of $47.19 \%$ in this role, the most common by a significant margin, as seen from table 5 . 
Table 5. Republika's most common political function and role ordered based on the $\Sigma \mathrm{x}$

\begin{tabular}{|c|c|c|}
\hline Function; role & Words & $\begin{array}{c}\text { Sum of } \\
\text { comparative } \\
\text { percentage }(\Sigma x)\end{array}$ \\
\hline $\begin{array}{l}\text { Informational - } \\
\text { instructive; } \\
\text { disseminator } \\
\text { Informational - } \\
\text { instructive; } \\
\text { storyteller }\end{array}$ & $\begin{array}{l}\text { president, percent, candidate, } 2019 \text {, number, voice, } \\
\text { pairing, Jakarta, party, chief, presidential candidate, } \\
\text { grand, vice, debate, one, state, vice presidential } \\
\text { candidate, people, mass, April, event, general, national, } \\
\text { present, supporters, big, good, city, stadium } \\
\text { prabowo, jokowi, indonesia, maruf, sandiaga, amin, } \\
\text { kiai, subianto, widodo, politics, joko }\end{array}$ & $\begin{array}{l}47.19 \% \\
34.03 \% \\
\end{array}$ \\
\hline
\end{tabular}

Republika reported on topics, such as both 2019 presidential and vice-presidential candidacies (2019, x:2.53\%; president, x:4.05\%; calon, $\mathrm{x}: 2.98 \%$; capers, $\mathrm{x}: 1.68 \%$; wakil, $\mathrm{x}$ : $1.58 \%$; cawapres, $\mathrm{x}: 1.12 \%$ ), as well as the development of the capital and country (Jakarta, $\mathrm{x}: 2.03 \%$; Negara, $\mathrm{x}: 1.13 \%$; Nasional, $\mathrm{x}: 1.07 \%$ ) all in the disseminator capacity. As such, it becomes apparent that voa-islam.com indulges in more framing and questionable reporting; the post-truth phenomena about Go and Lee [4], and Arno's (1984) view on the media's ability to accentuate conflict [30]. Additionally, the framing of conflict by voa-islam.com is incredibly petty, in line with Strömbäck and Van Aelst's [17] findings. On the other hand, Republika holds itself to greater impartiality compared to voa-islam.com.

That being said, it is important to note that the second most common function in Republika reporting is the aforementioned storyteller role $(\Sigma \mathrm{x}: 34.03 \%)$; found when covering both presidential candidates (Prabowo, x:8.12\%; Subianto, x: 1.35\%; Jokowi, x:7.94\%; Joko, x: $1.31 \%$; Widodo, $\mathrm{x}: 1.32 \%$ ) and their vice-presidential candidates (Sandiaga, $\mathrm{x}: 2.66 \%$; Sandi, $\mathrm{x}: 2.37 \%$; Maruf, x:2.68\%; Amin, x:1.76\%, Kiai, x:1.72\%). This research found that Republika's reporting provided context and building frames on Prabowo as statesmanlike, Jokowi as a political phenomenon, Sandiaga as a man of the people, and Maruf, the religious cleric; provided each individual equal coverage. In Republika's capacity as a media practicing Islamic journalism, reporting remains by and for the Muslim population, as Republika articles were found to have been written with Islam's best interest in mind. As such, the framing of each candidate can be chalked down to Cammaerts and Carpentier's [15] and Inglehart's arguments [6], as the framework of religion always has the inherent potential to skew reporting, and this subjectivity captures the grassroots framework of democracy. Unlike voa-islam.com, however, Republika reported both the negative and positive aspects of each candidate instead of indicating clear favoritism. When contrasting all the keywords head-to-head, voa-islam.com's reporting of the 2019 presidential election can be found to adopt the 'us and them' mindset, as previously stated by Hameleers and Schmuck [32].

\section{Conclusion}

In line with Muchtar et al.'s [12] definition, this research surmised that the brand of Islamic journalism practiced by voa-islam.com and Republika reported the 2019 Indonesian presidential election in catering to the Muslim voters; akin to the ummat concept. The focus of reporting can 
be denominated to the objectification of political and societal issues, as forewarned by Arifuddin [13], but from a Muslim perspective that caters to the protection and promotion of Islamic interests. Regarding the political function of such a manner of reporting, voa-islam.com has been found to stray away from the basic journalistic principle of impartiality admittedly, going out of its way to actively promote presidential candidate Prabowo Subianto at the expense of Joko Widodo. On the other hand, as the more mainstream and widely read media, Republika provided equal and impartial coverage, although still denominated from the aforementioned Muslim perspective.

This research concludes that the relationship between Islamic journalism's focus of reporting on the 2019 Indonesian presidential election and its politically oriented journalistic roles, as compared to the mainstream media, is one of contextualizing issues from an Islamic point of view; with voa-islam.com seemingly involved in a violent 'us against them' mindset in equating support for Prabowo to be support for the protection of Muslim integrity in Indonesia. In short, the role of voa-islam.com's Islamic journalism reporting boils down to the active contextualization and framing of Prabowo as the superior choice for its readers demography; this essentially boils down to the idea that support for Prabowo, can equate to negative reporting for the other presidential candidate, Joko Widodo.

\section{References}

[1] Nordholt H. Identity Politics, Citizenship and the Soft State in Indonesia: an Essay. Journal of Indonesian Social Sciences and Humanities. 2018;1(1). Available from: https://doi.org/10.14203/jissh.v1i1.1

[2] Fenton N. New media, old news. 1st ed. SAGE Publications Ltd.; 2009. Available from: https://www.academia.edu/1593040/Natalie_Fenton

[3] Miller S. Citizen Journalism. Oxford Research Encyclopedia of Communication. 2019. Available from: https://doi.org/10.1093/acrefore/9780190228613.013.786

[4] Go S, Lee M. Analysis of Fake News in the 2017 Korean Presidential Election. Asian Journal for Public Opinion Research [Internet]. 2020 May 31;8(2):105-25. Available from: https://doi.org/10.15206/AJPOR.2020.8.2.105

[5] B J. Religion and Democracy. Sociology and Criminology-Open Access. 2016;04(02). Available from: https://doi.org/10.4172/2375-4435.1000152

[6] Vlas N, Gherghina S. Where does religion meet democracy? A comparative analysis of attitudes in Europe. International Political Science Review. 2012;33(3):336-351. Available from: https://doi.org/10.1177/0192512111415983

[7] Aminuddin M. [Internet]. Media.neliti.com. 2021 [cited 13 June 2021]. Available from: https://media.neliti.com/media/publications/103662-electoral-system-andparty-dimension-ass-c44c408b.pdf

[8] Freedman A, Tiburzi R. Progress and Caution: Indonesia's Democracy. Asian Affairs: An American Review. 2012;39(3):131-156. Available from: https://doi.org/10.1080/00927678.2012.704832

[9] HerdiansahA, Sumadinata W. Indonesia's political culture in the new digital age: A preliminary discussion. Masyarakat, Kebudayaan dan Politik. 2019;32(4):378. Available from: https://doi.org/10.20473/mkp.v32i42019.378-389

[10] Irawanto B. Making It Personal: The Campaign Battle on Social Media in Indonesia's 2019 Presidential Election [Internet]. Singapore: ISEAS; 2019. Available from: https://www.iseas.edu.sg/images/pdf/ISEAS_Perspective_2019 28.pdf 
[11] Hasan N, Dauda S. Roles of Malaysian Online Newspapers in the Construction of Public Opinion on Rare Earth Risks. Asian Journal of Public Opinion Research [Internet]. 2020;8(4). Available from: https://www.ajpor.org/article/18114-roles-ofmalaysian-online-newspapers-in-the-construction-of-public-opinion-on-rare-earth$\underline{\text { risks }}$

[12] Muchtar N, Hamada B, Hanitzsch T, Galal A, Masduki, Ullah M. Journalism and the Islamic Worldview. Journalism Studies. 2017;18(5):555-575. Available from: https://doi.org/10.1080/1461670x.2017.1279029

[13] Saifuddin M. Why Political Parties Colonize the Media in Indonesia: An Exploration of Mediatization. Jurnal Ilmu Sosial dan Ilmu Politik. 2017;20(1):16. Available from: https://doi.org/10.22146/jsp.17994

[14] Tapsell R. Indonesia's Media Oligarchy and the "Jokowi Phenomenon." Indonesia. 2015;(99):29. Available from: https://doi.org/10.5728/indonesia.99.0029

[15] Cammaerts B, Carpenter N. Reclaiming the media. Bristol: Intellect; 2007.

[16] Masduki M. Media and Politics: Re-Thinking the Indonesian Broadcasting System. Jurnal Ilmu Sosial dan Ilmu Politik. 2017;21(1):14. Available from:

https://doi.org/10.22146/jsp.28680

[17] Strömbäck J, Van Aelst P. Why political parties adapt to the media. International Communication Gazette. 2013;75(4):341-358.

https://doi.org/10.1177/1748048513482266

[18] Hjarvard S. The mediatization of religion: A theory of the media as agents of religious change. Northern Lights: Film and Media Studies Yearbook. 2008;6(1):926. Available from: https://doi.org/10.1386/nl.6.1.9_1

[19] Witte M. Religion and Media. The International Encyclopedia of Anthropology. 2018;:1-5. Available from: https://doi.org/10.1002/9781118924396.wbiea2008

[20] Törnquist O. Muslim politics and democracy the case of Indonesia [Internet]. JOURNAL OF INDONESIAN ISLAM; 2007. Available from: https://media.neliti.com/media/publications/93592-EN-muslim-politics-anddemocracy-the-case-o.pdf

[21] Visser P, Holbrook A, Krosnick J. Theories of public opinion formation and change. [Internet]. Donsbach: Public Opinion Research; 2007. Available from: https://pprg.stanford.edu/wp-content/uploads/2008-Knowledge-and-AttitudesChapter.pdf

[22] McCombs M. Agenda Setting, Media Effects on. International Encyclopedia of the Social \& Behavioral Sciences. 2015:351-356. Available from: https://doi.org/10.1016/B978-0-08-097086-8.95007-4

[23] Wang T-L. Does Fake News Matter to Election Outcomes? The Case Study of Taiwan's 2018 Local Elections. Asian Journal for Public Opinion Research [Internet]. 2020 May 31;8(2):67-104. Available from: https://doi.org/10.15206/AJPOR.2020.8.2.67

[24] Hanan D. IDENTITY POLITICS IN THE 2019 INDONESIAN GENERAL ELECTIONS: ITS SIGNIFICANCE AND LIMITATION. JWP (Jurnal Wacana Politik). 2020;5(1):15. Available from: https://doi.org/10.24198/jwp.v5i1.27710

[25] Fossati D. The Resurgence of Ideology in Indonesia: Political Islam, Aliran and Political Behaviour. Journal of Current Southeast Asian Affairs. 2019;38(2):119-148. Available from: https://doi.org/10.1177/1868103419868400 
[26] Törnquist O. Many Votes, Little Voice: Indonesia's 2019 Presidential and Parliamentary Elections. Pacific Affairs. 2019;92(3):459-474. Available from: https://doi.org/10.5509/2019923459

[27] Hapsari T B. The History of Contemporary Indonesian Muslim Groups and Muslim Media. Afkaruna. 2018;14(1). Available from:

https://doi.org/10.18196/aiijis.2018.0082.101-127

[28] Hamada B. Towards a global journalism ethics model: an Islamic perspective $\dagger$. The Journal of International Communication. 2016;22(2):188-208. Available from: https://doi.org/10.1080/13216597.2016.1205506

[29] Hamidah K. The Trend of Emerging Identity Politics in Indonesia and the Challenge in Fostering Social Cohesion: Lesson Learned from Jakarta Provincial Election. KARSA: Journal of Social and Islamic Culture. 2018;26(1):91. Available from: https://doi.org/10.19105/karsa.v26i1.1653

[30] Sasangka D. The Potential Role of News Media in the Regional Conflict: Reading the Representation of the Potential Role of Indonesian News Media in the Conflict over Ambalat Disputed Island between Indonesia and Malaysia. Jurnal ILMU

KOMUNIKASI. 2013;2(2). Available from: https://doi.org/10.24002/jik.v2i2.244

[31] David S, Ongis M. The politics of zero-sum thinking: The relationship between political ideology and the belief that life is a zero-sum game. Science Advances. 2019;5(12). Available from: https://doi.org/10.1126/sciadv.aay3761

[32] Hameleers M, Schmuck D. It's us against them: a comparative experiment on the effects of populist messages communicated via social media. Information, Communication \& Society. 2017;20(9):1425-1444. Available from: https://doi.org/10.1080/1369118x.2017.1328523

[33] Hanitzsch T, Vos T. Journalism beyond democracy: A new look into journalistic roles in political and everyday life. Journalism. 2016;19(2):146-164. Available from: https://doi.org/10.1177/1464884916673386

[34] Mahfud C. Ideologi media islam indonesia dalam agenda dakwah: Antara jurnalisme profetik dan jurnalisme provokatif [Internet]. Jurnal Dakwah; 2014. Available from: https://media.neliti.com/media/publications/77603-ID-ideologi-media-islamindonesia-dalam-age.pdf

[35] Rahman D, Adiprasetio J, Janitra P. The Representation of Democracy in Islamic News Sites Voa-Islam and ArRahmah. Jurnal The Messenger. 2018;10(1):14. Available from: https://doi.org/10.26623/themessenger.v10i1.604

[36] Macnamara J. Content Analysis. Mediated Communication. 2018;191-212. Available from: https://doi.org/10.1515/9783110481129-012

[37] Connolly-Ahern C, Ahern L, Bortree D. The Effectiveness of Stratified Constructed Week Sampling for Content Analysis of Electronic News Source Archives: AP Newswire, Business Wire, and PR Newswire. Journalism \& Mass Communication Quarterly. 2009;86(4):862-883. Available from: https://doi.org/10.1177/107769900908600409

[38] Hester J, Dougall E. The Efficiency of Constructed Week Sampling for Content Analysis of Online News. Journalism \& Mass Communication Quarterly. 2007;84(4):811-824. Available from: https://doi.org/10.1177/107769900708400410

[39] Neuendorf K, Skalski P. Quantitative Content Analysis and the Measurement of Collective Identity. Measuring Identity. :203-236. Available from: https://doi.org/10.1017/cbo9780511810909.008 
[40] Boettger R, Palmer L. Quantitative Content Analysis: Its Use in Technical Communication. IEEE Transactions on Professional Communication. 2010;53(4):346-357. Available from: https://doi.org/10.1109/tpc.2010.2077450

[41] Gandasari D, Dwidienawati D. Content analysis of social and economic issues in Indonesia during the COVID-19 pandemic. Heliyon. 2020;6(11):e05599. Available from: https://doi.org/10.1016/j.heliyon.2020.e05599

[42] Neuendorf K. Content analysis and thematic analysis. New York: Routledge: Research methods for applied psychologists: Design, analysis, and reporting; 2019.

[43] Kleinheksel A, Rockich-Winston N, Tawfik H, Wyatt T. Demystifying Content Analysis. American Journal of Pharmaceutical Education. 2019;84(1):7113. Available from: https://doi.org/10.5688/ajpe7113

[44] Krippendorff K. Reliability in Content Analysis. Human Communication Research. 2004;30(3):411-433. Available from: https://doi.org/10.1111/j.14682958.2004.tb00738.x

[45] Krippendorff K. Computing Krippendorff's Alpha-Reliability [Internet]. ScholarlyCommons. 2011 [cited 13 June 2021]. Available from:

https://repository.upenn.edu/asc_papers/43 